\title{
РІШЕННЯ РІВНЯННЯ КОЛИВАНЬ У ВИПАДКУ РЕЗОНАНСУ ОПРОМІНЮЮЧОГО РАДІОСИГНАЛУ І КРИСТАЛІЧНОЇ СТРУКТУРИ РАДІОПОГЛИНАЮЧОЇ КОМПОЗИТНОЇ РЕЧОВИНИ
}

\begin{abstract}
Анотація: Запропоновані в статті підходи можуть бути реалізовані на етапах отримання інформації і автоматичного супроводження РЛС сучасних літальних апаратів.

Ключові слова: радіолокаційна інформація, методи локації, опромінення, резонансна взаємодія, кратність частот.
\end{abstract}

\section{Вступ}

У якості аналізу слід зазначити, що сучасна техніка створюеться з використанням неметалічних матеріалів у своєї конструкції [1]. Це зрозуміло за рядом причин, основною з яких $є$ кращі характеристики речовин, що використовуються. Існуючі підходи [1] щодо отримання радіолокаційної інформації про такі об'єкти є непідходящими оскільки вони засновані на використанні ефректів, що протікають в металах під час їх опромінення електромагнітним НВЧ полем.

Проблемою е створення умов щодо дистанційної тимчасової зміни провідних властивостей для використання викликаних ефектів у існуючих способах радіолокації.

Тенденція розвитку сучасних літальних засобів полягає у використанні неметалічних композитних матеріалів у конструкції планеру. Цей напрямок суттево знижуе можливості існуючих радіолокаційних засобів по виявленню та супроводженню таких літальних апаратів. Основний недолік існуючих метолів локації літальних апаратів полягає у використанні принципу „потужного сигналу”, тобто збільшенні потужності випроміненого зондуючого сигналу для підвищення рівня віддзеркаленого від повітряного об'єкту радіолокаційного сигналу і покращення прийомних характеристик РЛС виявлення.

Метою дослідження є відсутність теоретично обгрунтованих методів локації повітряних цілей зі штучно зниженою площею віддзеркалення за допомогою спеціальних (резонансних) сигналів.

\section{Основна частина}

Для теоретичного обгрунтування можливості локації повітряних апаратів зі штучно зниженою площею віддзеркалення розглядається випадок, коли частота випроміненого зондуючого сигналу дорівнюе (або кратна) частоті власних коливань елементарних частинок речовин, з яких виготовляється композитний матеріал конструкції літального апарату.

(c) I.P. Пархомей, А.Д. Лемешко, 2011 
Цей випадок характеризуеться тим, що механічні коливання кристалічної структури речовини, що розглядається, не мають внутрішнього опору, тобто відсутня амортизація. Електричні властивості еквівалентних коливальних контурів кристалічної решітки відповідають тому, що опір $R=0$, що означає відсутність внутрішнього опору ланок. Рівняння взаємодії сигналу опромінення з коливальною структурою радіо поглинаючого композитного матеріалу прийме наступний вигляд (1):

$$
\frac{d^{2} x}{d t^{2}}+K^{2} x=A \sin \omega t
$$

де $x$ - лінійне відхилення атома від позиції в кристалічній решітці;

$t$ - час;

$K$ - частота власних коливань кристалічної решітки;

$A$ - амплітуда сигналу опромінення;

$\omega$ - частота сигналу опромінення.

Для результуючого значення резонансного сигналу взаємодії [2] рішення рівняння (1), що задовольняе початковим умовам: $t=0, x=x_{0}=0$, буде мати вигляд

$$
x_{\text {рез }}(t)=\frac{A}{\left(K^{2}-\omega^{2}\right) K}(-\omega \sin K t+K \sin \omega t) .
$$

Вираз у скобках рівняння (2) представляе собою суму двох гармонійних коливань: власних, з частотою $K$

$$
x_{C}(t)=-\frac{A}{K^{2}-\omega^{2}} \frac{\omega}{K} \sin K t,
$$

та вимушених, з частотою $\omega$

$$
x_{B}(t)=\frac{A}{K^{2}-\omega^{2}} \sin \omega t .
$$

Під час короткотермінової резонансної взаємодії процес буде характеризуватися залежністю $e^{-n t}(n-$ число кратності частот взаємодіючих коливань) і буде являти собою затухаючі коливання. Це характерно для опромінення імпульсними сигналами. За умови достатньо великого часу взаємодії, наприклад, при опроміненні квазібезперервним НВЧсигналом, характер резонансної взаємодії буде описуватися виразом

$$
x(t)=\frac{A}{\left(K^{2}-\omega^{2}\right)^{2}+4 n^{2} \omega^{2}}\left(\left(K^{2}-\omega^{2}\right)^{2} \sin \omega t-2 n \omega K \cos \omega t\right)
$$

На рис. 1 схематично наведений характер коливань для випадку, коли $K>\omega$ :

Якщо ввести позначення

$$
\frac{A\left(K^{2}-\omega^{2}\right)}{\left(K^{2}-\omega^{2}\right)^{2}+4 n^{2} \omega^{2}}=M \cos \delta,-\frac{A 2 n \omega}{\left(K^{2}-\omega^{2}\right)^{2}+4 n^{2} \omega^{2}}=M \sin \delta,
$$

де $M=\frac{A}{\sqrt{\left(K^{2}-\omega^{2}\right)^{2}+4 n^{2} \omega^{2}}}$, то рішення рівняння (5) можна записати як 


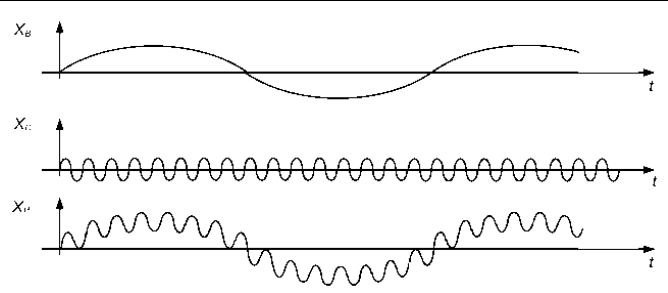

Рис. 1 - Модуляція власних коливань кристаличної решітки вимушеними електромагнітними коливаннями

$$
x(t)=\frac{A}{K^{2} \sqrt{\left(1-\frac{\omega^{2}}{K^{2}}\right)^{2}+4 n^{2} \frac{\omega^{2}}{K^{4}}}} \sin (\omega t+\delta) .
$$

Для випадку резонансної взаемодії як по частоті так і по фазі вираз (1) в операторному вигляді можна записати як

$$
x(p)\left(p^{2}+K^{2}\right)=A \frac{K}{p^{2}+K^{2}},
$$

де $x(p)=\frac{A K}{\left(p^{2}+K^{2}\right)^{2}}$,

$p$ - оператор Лапласа.

Зображення (8) є правильна раціональна дріб, початкова функція якої має вигляд

$$
\frac{K}{p^{2}+K^{2}}=\int_{0}^{\infty} e^{-p t} \sin K t d t .
$$

Після проведення диференціювання обох частин рівняння (9) за $K$, представивши інтеграл правої частини рівняння у вигляді суми двох інтегралів дійсної змінної, кожна з яких залежить від параметра $K$ :

$$
\frac{1}{p^{2}+K^{2}}-\frac{2 K^{2}}{\left(p^{2}+K^{2}\right)^{2}}=\int_{0}^{\infty} e^{-p t} t \cos K t d t .
$$

Використовуючи рівняння (9), вираз (10) можна записати у вигляді

$$
-\frac{2 K^{2}}{\left(p^{2}+K^{2}\right)^{2}}=\int_{0}^{\infty} e^{-p t}\left(t \cos K t-\frac{1}{K} \sin K t\right) d t .
$$

3 (11) витікае, що

$$
\frac{A K}{\left(p^{2}+K^{2}\right)^{2}} \div \frac{A}{2 K}\left(\frac{1}{K} \sin K t-t \cos K t\right) .
$$


Виходячи з цього, сигнал резонансної взаємодії опромінюючого і власного електромагнітного коливання буде описуватися виразом

$$
x_{\text {рез }}(t)=\frac{A}{2 K}\left(\frac{1}{K} \sin K t-t \cos K t\right),
$$

який може використовуватись в перспективних радіолокаційних станціях для виявлення та супроводження повітряних цілей зі штучно зниженою площею віддзеркалення.

\section{Висновки}

Слід зазначити, що при кратності частот опромінюючого сигналу і частоти внутрішніх коливань кристалічної структури радіопоглинаючої речовини амплітуда результуючого резонансного сигналу самовипромінення буде збільшуватися в $4 A^{2}$ рази, а внутрішній опір радіопоглинаючого діелектрика $R \rightarrow 0$;

під час збільшення часу резонансного опромінення $(t \rightarrow \infty)$ амплітуда результуючого резонансного сигналу самовипромінення необмежено зростає $\left(A_{\text {рез }} \rightarrow \infty\right)$ за умови не тільки частотного, але і фазового резонансу.

\section{Література}

1. Несветей Э.А. Специальные вопросы радиоэлектроники. - К.: Киев, Изд-во ВА ПВО, 1990 г. - 416с.

2. Пискунов И.В. Операционное исчисление и некоторые вопросы его приложения. - М.: Москва, Изд-во “Высшая школа”, 1986г. - 850с.

Отримано 12.03.2011 p. 